\title{
Masculinity Construction in Apple Iphone 7 Plus Commercials: "The Rock X Siri - Dominate the Day and the Dive"
}

\author{
Nico Christiawan Untaryo \\ English Department, Faculty of Letters, Petra Christian University Surabaya, East Java, Indonesia \\ e-mail: nicochristiawan@gmail.com
}

\begin{abstract}
This study is conducted to reveal the masculinity construction in the commercial of Apple iPhone 7 Plus The Rock x Siri - Dominate The Day and The Dive. The writer use Masculinity concept as a guideline and Gillian Dyer's list the theory of human signs (1982) to examine the visual signs in both of the commercial videos. The elements that analyze are appearance, manner, and activity. In the analysis, the commercials show masculinity as having confidence, dedication and freedom. Confidence are shown from the appearance, manner and activity, Dedication and Free are shown from the activity. To conclude The Rock $x$ Siri-Dominate The Day and The Dive can be a new reflections of today's masculinity while promoting their product.

Keywords: Commercial video, Apple commercial, Masculinity
\end{abstract}

\section{INTRODUCTION}

Commercial is one of the most influencing elements of promoting products and services. Commercial is different from Advertisement. Commercial is an advertisement on the radio or on television (Oxford advanced learner's dictionary 8th edition, 2010) yet is not limited on those media; nowadays commercial is also broadcasted on the internet and Ads (advertisements) are typically considered as a printed media, such as magazines, newspaper, or yellow pages. Apple Company's commercials are always interesting because they are quick, eye-catching, and unique. It is also able to deliver lots of information and values in the short period of time, Apple Company's commercials have successfully created a massive number of viewer back then in 1984 which helps the company in positioning as a leader of industry. in 1984 they won a Clio award as 'The Greatest TV ad of all time' (Insider, B., 2017), with such award, Apple commercial could reflect a particular social issues. At that time the commercial issues the women's movement in 1980s (Burkett, 2016). Afterward, Apple commercial in these days try to reflect social issues which is masculinity. Masculinity seems to be an issue in these days, there are several articles and talkshows on the internet trying to breakdown what masculinity is.

The writer chose two Apple iPhone 7 Plus plus commercials because it is constructed masculinity as the main idea of both commercials, Masculinity is interesting to be analyzed because it keeps changing time by time from the past (traditional masculinity), then continued to developed as the new era comes as twentieth century masculinity and now the other perspective of masculinity in which portrayed in Apple iPhone 7 Plus plus commercial; which are The Dive uploaded on November 2nd 2016, It was telling about an old man who wants to jump off from the diving platform, it is introducing the speakers of Apple iPhone 7 Plus that has a splash-proof feature. And then The Rock $x$ Siri Dominate The day It is telling about a Hollywood male celebrity, Dwayne Johnson as known as The Rock, fulfilling his life goals assisted with his virtual assistant Siri in his iPhone 7 Plus Plus,. Apple uses visual components to construct Masculinity through these two commercials.

The construction in these two commercial videos is shown through the main characters' actions, appearance, characteristics and goals. The writer is interested in how Apple constructs masculinity in the two commercials. The writer's analysis will go through those components and It 
will prove that both of the commercial: The Dive and The Rock $x$ Siri - Dominate The Day commercial videos show characteristics that are constructed as masculine.

The masculinity that apple constructs will show that commercials may create a new perspective of masculinity while promoting its own products. Masculinity is a social construction that people address to men particularly what a man should do and how a man should be, including behaviors, languages and practices, existing in specific cultural and organizational locations.

Contemporary masculinity is masculinity defined and valid at same periods of time which refers to the temporary itself. Masculinity is different in each specific cultural and organizational area based on the behavior, norms and values of the society influence. Masculine traits or characteristics are actually things that people addressed to Human's behavior and practices. What they be and they do may reflect some particular values or characteristic in general by Jason Fonceca.

\begin{tabular}{|l|l|}
\hline Freedom & $\underline{\text { Passion }}$ \\
\hline Direction & $\underline{\text { Independence }}$ \\
\hline$\underline{\text { Logic }}$ & $\underline{\text { Discipline }}$ \\
\hline$\underline{\text { Focus }}$ & $\underline{\text { Confidence }}$ \\
\hline$\underline{\text { Integrity }}$ & $\underline{\text { Aware }}$ \\
\hline$\underline{\text { Stability }}$ & $\underline{\text { Strength }}$ \\
\hline
\end{tabular}

Table 1.1

\section{METHODS}

The writer identified masculinity construction that is shown in visual images of the video such as actions, appearance, and manner using visual methodologies. Specifically, the writer is using the visual methodology of Gillian Dyer's in which he applied to analyze photograph in advertisement 'The List of human signs' (1982) taken from Gillian Dyer's book titled Advertising as Communication in 1982. The method is using signs can be taken as human signifiers from a picture or images, including Bodies, Manner, and activity. In order to find three main things of masculinity which are constructed as confidence, dedication, and freedom. In this research The writer is using screenshots as the photagraphs of the commercial videos.

\section{ANALYSIS AND FINDINGS}

The writer used the Masculinity traits as a bridge to his findings, he have found three traits that are strongly shown in both commercial videos the first one is Confidence, The second is Dedication, and however dedication on the Masculine traits is actually divided into three traits which are Passion, Discipline, and Focus. And the last is Freedom.

\section{The Analysis of Masculinity Construction is shown as Confidence}

The definition of Confidence is a belief on one's self and one's ability to succeed. Confidence means an attitude that is based on being cool and comfortable with whom you are and what you like, because the key to real confidence is our reaction and our way dealing with the crappy stuff and for a confidence man, they will act like a gentleman (Helpern, J., n.d). The writer is going to analyze three points of confidence in the commercials that related to the masculinity construction including Bodies, Manner, and Activity.

First of all, Masculinity Construction is shown as Confidence in Appearance. There are two aspects of Appearances that the writer is going to analyze in both of the commercial The Rock $x$ Siri-Dominate The Day and The Dive. Which are age and hair, First, The writer found out that a man around 40s is at the golden age of creative (Feinn, 2017). And with that findings he related to the confidence and got a result that being creative is also a part of confidence because is related to the belief in yourself in order to develop and explore the creativity. 
Second, The Dive uses the actor Enzo maiorca, who was born in 1931, he is 85 years old. The Actor is shown to have the unusual activity in the public swimming pool. A poll done by Gallup an analytics and advice company which specialty in attitudes and behavior of the people also finds that the older men get, like at 65 or older, They better they felt about physical appearance, simply means that he is able to respect himself as he is. "Sixty-six percent of those 65 and older "agreed" or "strongly agreed" with the statement ...” (Feinn, 2017).

Next, The commercial uses bald hairstyle of their actor The Rock has some proposed aspect to show confidence. The writer found Apple chose a particular hair to show confidence based on the study which was conducted in University of Pennsylvania by Albert. E Mannes finds bald men are more confidence and stronger.

Other things, Apple commercial uses an original hair of this actor in the commercial "The Dive" to show the confidence. The writer analyzed the commercial which deliberately lets the original hair which is the hair loss of the actor seen rather than covering it with black scalp powder. It comes to a result which is a will of confidence that let the actor feels comfortable about the looks especially his hair.

First of all, the definition of Manner. Manner is a way of something is being done or happens; it is based on the mode of action or behavior. "Manner is a way of doing, being done, or happening; mode of action, occurrence" (Dictionary, n.d)There are three aspects of Manner that The writer is going to analyze, which are expression, eye contact and pose. Those three parts of manner The Rock x Siri-Dominate The Day and The Dive are showing confidence in each of the commercial video.

Second of all, Masculinity Construction is shown as Confidence in Manner. Manner that shows confidence is expression of the main character in commercial video The Rock $x$ Siri-Dominate The Day. The Rock is shown to express sternness and serious to hear the news about underestimating him, that he could not finish all his life goals.

The writer has analyzed The Rock posture shown while he was talking to the online taxi driver, this action considered as showing confidence because his eye contact was straightly on the driver's eyes. He leans forward to convince him for driving his car. The study says that a person who frequently keeps his eye contact is having higher self-esteem and those who are the opposite which are frequently breaks eye-contact are having lower self-esteem (Umoh, R. 2017).

Meanwhile the writer also found other things about confidence in manner on the second commercial The Dive. The main character looks relaxed before climbing up the diving platform. Because it is only a confident man who looks forward, Looking forward indicated confidence because lowering head slightly and watching steps communicates to others that you don't want to engage in conversation or interact (AskMen, n.d).

Third of all, Masculinity Construction is shown as Confidence in Activity. There are some activities in two commercial videos that The writer analyzed The Rock actions of being a pilot. He found out that talks which can convinced people is a confident because it uses one out of six principles in persuasion by Dr. Robert Cialdini (Cialdini R, n.d)

Next, the other analyses are done at the scene where The Rock act in a scenario of a film titled NEO ATOMICA. The writer found that Rock is successfully finishing 1 take for the scene. The writer found out that The Rock's action in finishing only one take is related to the qualities of a great actor that is able to convince people and the acting believable with confidence (Theatre school, n,d)

Last, The writer was also analyzed on Enzo Maiorca (main character) who could climb and reach the top of the platform to do a free diving action The writer found out on the other research 
that not all professionals or athlete is confidence to face the fear of being failure (falling) (Latimer, 2017) and the fear itself become the obstacle of being succes but confidence can conquer it.

\section{The Analysis of Masculinity Construction is shown as Dedication}

The definition of Dedication is a commitment to something that someone really likes by giving their time and energy related to his or her personal goals (dictionary.com, n.d). It is often called as the same as faithfulness.

First, what the writer is found on the activity is that Apple commercial uses main character's activities to show masculinity construction as dedication. First, The Rock is able to maintain both of his interests which are body building and planting a bonsai that needs personal dedication." (Verdissimo, 2016)

Second, Masculinity constructed as dedication in the commercial video using the main character's activity. The Rock activity that shows dedication is painting, Famous and successful painting artists knows their time to produce their art. "Successful artists are dedication to their creative efforts. They are consistently and constantly in the studio producing." (Horejs. J. J. , n.d) The Rock is shown to be repainting a painting picture in a building It needs dedication by giving lot of time and effort to do such thing, because the goal is not making it good but making it as close as the original, in this case painting.

Another thing, Masculinity constructed as dedication in the commercial video The Rock $\mathrm{x}$ Siri - Dominate the Day using the main character's activity. The Rock's activity that shows dedication is cooking; Cooking is not an easy thing, it needs dedication which involved patience, a patience to give your time and effort fully to the thing that you do. The Rock really uses his effort to make a precise measurement of sauce by using his iPhone's virtual assistant 'Siri' to get the proper measurement of sauce.

Next, Masculinity constructed as dedication also found in the commercial video The Rock $\mathrm{x}$ Siri - Dominate the Day. The writer has found that a musical instrument that The Rock played is considered as one of the most complicated instruments in the world the epoch times reported (Ford. C. - Wu. A, 2013). And it needs a lot of dedication to play that musical instruments

Last, Masculinity constructed as dedication in the commercial video The Dive using the main character's activity. The main character Enzo Maiorca's activity that shows dedication is jumping from the diving platform, it is the same as free-diving, free-diving requires relies on the ability of divers like holding breath to be under the water. the main character fulfilled the basic techniques of diving like stretched his arms before he jumps and he takes a breath and time also passion that is able to develop that such diving skill.

\section{The Analysis of Masculinity Construction is shown as Freedom}

The definition of freedom is the power or right to act, speak, or think as one wants without hindrance or restraint. (Oxford-dictionary, n.d). This definition is applicable in the context of constructing masculinity. It is seen that men always have a freedom to do whatever he wants to do.

The writer has found a Masculinity Construction is shown as Freedom in Activity. He found out that Apple commercial uses main character's activities to show masculinity constructed as freedom. Freedom in this scene is the idea of free-will that is able to have a full-control of his live because the idea of free-will is giving people a feeling of control over their lives (Griffin, A, 2016). The Rock is a well-known actor with tight schedule (25 appointments), but The Rock has chosen to get out of his daily activities such as schedules and appointments. The writer found that The Rock's breaking-free is one of the characteristic that could construct masculinity.

Second of all, Apple commercial uses main character's activities to show masculinity construction as free. The Rock held a fashion runaway. Free in this scene was specifically referred to the freedom of expression. In this scene, The Writer found out that fashion is used by The Rock 
as a media to express his feeling freely especially his thought about life should be balanced although what he made was a women's dress.

In The Dive commercial videos that The writer analyzed, there is an activity that is constructing masculinity as free. He freed himself from the stereotype that people address to an old man like him in the certain area, especially swimming. Like for example, old people mostly when they are in the swimming pool, they mostly seen in the swimming pool bench, sitting and sunbathing, or others they just swim harmlessly avoiding jumps and dive, but this main character. He chose to express his will into the free dive and he does not want to be tied with the stereotypes and he chose to declare his own freedom by doing that

\section{CONCLUSION}

In conclusion, The writer have found that Apple Commercial videos used visual images in Apple iPhone commercials are created in such a way to construct masculinity. The visual images including appearance, manner and several activities of the main characters are constructing masculinity. These Masculinity that apple wants to show in their commercial had already construct a perspective of masculinity which are Confidence, Dedication, and Freedom. Moreover, with such ideas, Apple as a giant brand influences their audience's perspective toward masculinity while promoting its own products.

AskMen. (2011). Top 10 Ways to Show Confidence With Body Language. Retrieved from http://www.foxnews.com/health/2011/09/13/top-10-ways-to-show-confidence-with-bodylanguage.html

Burkett, E. (2016). Women's movement. Retrieved from https://www.britannica.com/topic/womens-movement

Cialdini R. (n.d.). The 6 Principles of Persuasion by Dr. Robert Cialdini [Official Site]. Retrieved from https://www.influenceatwork.com/principles-of-persuasion/

Dictionary. (n.d.). Dedication Retrieved from http://www.dictionary.com/browse/dedication

Feinn, L. (2017). The Ages You Are Happiest, Most Creative, And Most Confidence. Retrieved from https://www.bustle.com/p/these-are-the-ages-you-are-happiest-most-creative-mostconfidence-61967

Ford. C. - Wu. A (2013, July 19). The Guqin: 'Instrument of the Sages'. Retrieved from https://www.theepochtimes.com/the-guqin-instrument-of-the-sages_187835.html

Freedom (n.d.). Definition of free in English by Oxford Dictionaries. Retrieved from https://en.oxforddictionaries.com/definition/freedom

Griffin, A. (2016). Free will could all be an illusion, scientists suggest after study shows choice may just be brain tricking itself. Retrieved from https://www.independent.co.uk/news/science/free-will-could-all-be-an-illusion-scientistssuggest-after-study-that-shows-choice-could-just-be-a7008181.html

Helpern, J. (n.d.). What Being Truly Confidence Means. Retrieved from https://www.askmen.com/dating/heidi/what-does-confidence-mean.html

Horejs. J. J. (n.d.). Retrieved from https://reddotblog.com/5-strategies-successful-artists-follow-tothrive-in-their-careers/

Insider, B. (2017,). The best Apple ad from each year since its 1984 Super Bowl hit. Retrieved from http://www.businessinsider.com/apple-history-through-advertising-40-yearsanniversary-2017-2/?IR=T\%2F\#1984-1984-1

Latimer (n.d) Why the best high divers are actually afraid | Fina Retrieved from://www.fina.org/news/why-best-high-divers-are-actually-afraid

Dictionary (n.d.). Manner. Retrieved from http://www.dictionary.com/browse/manner

Hornby, A. S., \& Turnbull, J. (2010). Oxford advanced learners dictionary of current English.

Oxford: Oxford University Press.

Umoh, R. (2017). How making eye contact can help you appear more confidence at work. Retrieved from https://www.cnbc.com/2017/08/17/how-making-eye-contact-can-help-youappear-more-confidence-at-work.html 
Verdissimo (2016). Tools you won't need for your preserved bonsai. Retrieved from https://www.verdissimo.com/en/news/tools-you-wont-need-for-your-preserved-bonsai 